\title{
PRESS FREEDOM IN SINGAPORE AND MALAYSIA: DEFAMATION AND OTHER CONSTRAINTS
}

\author{
Georgia Kate Chapman \\ Law School, University of Wollongong
}

\begin{abstract}
This paper focuses on the arguments around restriction on freedom of the press in the Strong States of Singapore and Malaysia. It assesses the presence of constraints on press freedoms in democratic western countries imposed by corporation rather than the nations and the similar effects that these constraints may have on the bias present in publicly accessible news reporting. It argues that independence of the press does not only require protection from legal and executive regulation, but also protection from large media corporations and their political alignments. This report will assess the bias of reporting and news media publication that exists in Malaysia and Singapore due to legislative and regulatory constraints as opposed to the bias that exist in the western liberal democratic nations of the United Kingdom (UK) and the United States of America (USA) due to Media Organisation control.
\end{abstract}

Key words: freedom of press, publication control, media and politics.

\section{INTRODUCTION}

Civil defamation law limits the capacity of media outlets to report the news freely. There are ever present constraints to media from both corporate and political influences ${ }^{1}$. These create an interesting priority list; a hierarchy that does not put the interests of the individual and their access to accurate information first, or second.

Global media groups are the key social actors playing a large part in media accessibility; shaping the social world by exerting control over issue-framing and information gate keeping. One of the largest media organisations in the world, NewsCorp (top 5) is an example that will be used in this paper to outline influences on public's access to media in the liberal democracies of the UK and the USA. The separation of corporation and State from power is difficult and it is

1 Whiting and Majoribanks, (2013) 'Media Professionals' Perceptions of Defamation and Other Constraints upon News Reporting in Malaysia and Singapore' Democracy, Media and Law in Malaysia and Singapore 129. 
even harder to determine whether it is to be the direct dominator of the other ${ }^{2}$. This will assist in supporting the view that the power which large media organisations possess can have large influences over both politics and legislation; moreover, their use of this power in changing access to the media and journalist ability to freely express opinions ${ }^{3}$.

Defamation legislation and the application of this legislation and regulation in Malaysia, Singapore - as opposed to the UK and the USA - will support the argument that restrictive regulation creates political and corporate alignments over press freedom and public access to information. Freedom of expression and speech is topical around the world. Article 19 is an example of this international focus ${ }^{4}$.

\section{DEFAMATION LEGISLATION AND REGULATION}

\section{The United Kingdom (UK) and The United States of America (USA)}

In the UK, civil actions around defamation for damages may be made brought to the High Court if the statement is defamatory, identifies or refers to the claimant, and were published ${ }^{5}$. This is covered by the Defamation Act $2013^{6}$. The defamation against media generally deals with libel — the publication of a statement in permanent form, generally;
a. print,
b. broadcast on TV or radio,
c. film, and
d. Internet.

\footnotetext{
${ }^{2}$ Arsenault and Castells, (2008) 'Switching Power: Rupert Murdoch and the Global Business of Media Politics: A Sociological Analysis’ 23(488) International Sociology 489.

${ }^{3}$ Ibid.

4 Article 19 and Suaram, (2005) Freedom of Expression and the Media in Malaysia www.article19.org/data/files/pdfs/publications/malaysia-basline-study.pdf.

5 Defamation Laws in UK, 25/5/14, Kelly/Warner: International Defamation Law Legal Database, <http://kellywarnerlaw.com/uk-defamation-laws>/.

${ }^{6}$ Defamation Act 2013 (UK).
} 
The rule in Reynolds ${ }^{7}(\mathrm{UK})$ outlines recognition of 'responsible journalism', via a ten point test determining how information was collected and verified, and how consultative steps had been taken prior to publication ${ }^{8}$. It also addresses the urgency to publish. Thus, it is a public interest test rather than a political or economic test which allows individuals to represent themselves better or to publish media without any fear of litigation. This test ensures whether the information published is appropriately sought and presented.

In the USA, defamation legislation is dealt with by each individual state. It is also referred to as slander. Here, defamation is directly related to the First Amendment ${ }^{9}$; making a case in defamation much more difficult for a plaintiff to bring about; as opinion cannot be considered as defamation in the USA. Moreover, in this nation, service providers on the internet are not held to be accountable for defamatory statements made by visitors to their sites.

Large portions of the media outlets in both nations are owned by NewsCorp ${ }^{10}$. The influence of NewsCorp and the large political authorities within the UK and the USA will be investigated further in this article. In both of these democratic nations, defamation legislation is used predominantly by celebrities who feel that their image has been defamed in media.

\section{Malaysia and Singapore}

There are high levels of media regulation within both Malaysia and Singapore; both of which are non-liberal Asian democracies. Within non-liberal Asian democracies-sometimes referred to as semi or pseudo democracies ${ }^{11}$ - government regulation over access to media and

${ }_{8}^{7}$ Reynolds $v$ Times Newspapers Ltd [2001] 2.

8 Whiting and Majoribanks, (2013) 'Media Professionals' Perceptions of Defamation and Other Constraints upon News Reporting in Malaysia and Singapore' Democracy, Media and Law in Malaysia and Singapore 135.

${ }^{9}$ United States Constitution amend I.

${ }^{10}$ Arsenault and Castells, 'Switching Power: Rupert Murdoch and the Global Business of Media Politics: A Sociological Analysis, (2008), 23:488, International Sociology, 495.

${ }_{11}$ Whiting and Majoribanks, (2013) 'Media Professionals' Perceptions of Defamation and Other Constraints upon News Reporting in Malaysia and Singapore' Democracy, Media and Law in Malaysia and Singapore 131. 
press freedoms is high ${ }^{12}$. There is large political pressure on editors of publication, in order to ensure that information provided to the public is not damaging the powerful political parties of these nations.

In Singapore, the Newspaper and Printing Presses Act (NPPA) ${ }^{13}$ will not circulate foreign publications if they are seen to be detrimental to the local political regime ${ }^{14}$. These laws also require the possession of a licence for publishers to be able to release press to the public. The licensing has been-from interviewees - the most onerous element of the press freedom restrictions within Singapore ${ }^{15}$. This regulation is seen to be more restrictive than the defamation legislation itself - Defamation Act (cap. 75). In Singapore, it has been seen that in the court a media defendant has never succeeded against a government plaintiff ${ }^{16}$. This historical track has led to self-censorship by many journalists, for fear of financial consequences and licensing removals ${ }^{17}$. It is interesting to note that the Singaporean judicial system has not come under scrutiny of process. However, it is the restrictive legislation causing the removal of press freedoms and access to media for the public.

The Malaysian legal system has historically imposed temporary bans or content censorships on media that 'displeased the government ${ }^{18}$. Article 10 of the Malaysian Constitution guarantees the right to freedom of expression: 'every citizen has the right to freedom of speech and expression... All citizens have the right to assemble peaceably and without arms ${ }^{19}$, This right to freedom of expression has many restrictions placed on it. In

\footnotetext{
12 Ibid, 132.

${ }^{13}$ Newspaper and Printing Presses Act (rev. edn 2002).

${ }^{14}$ Whiting and Majoribanks(2013) 'Media Professionals' Perceptions of Defamation and Other Constraints upon News Reporting in Malaysia and Singapore' Democracy, Media and Law in Malaysia and Singapore, 132.

${ }^{15}$ Ibid, 142.

${ }^{16}$ Ibid, 136.

${ }^{17}$ Ibid, 132 and 145.

${ }^{18}$ Ibid, 132.

${ }^{19}$ Constitution of Malaysia 1957, art X.
} 
reality, it may lead to heavy fines or potentially a prison sentence ${ }^{20}$. It can be seen that there is also strict legislative control under the Printing Presses and Publications Act (PPPA) ${ }^{21}$. Due to these restrictions, there is an increasing level of self-censorship by editors and journalists to ensure that they are able to renew their publishing licences. The Royal Commission of Inquiry in 2007, following the 'Lingham Tape' matter, led to Malaysians and others being able to open a dialogue around the issues within the Malaysian Courts with regard to defamation cases for media publication.

The court system in Malaysia has come under scrutiny for the efficiency and transparency of its judiciary, following a group of highly contentious defamation cases in the 1990's where government and business interests were reported by international reporters and journalists. The damages awarded to the plaintiff's in these cases were exorbitant and received criticisms in an international sphere ${ }^{22}$. This belief that the courts 'defer to the State at the expense of the plaintiff's rights ${ }^{23}$, outlines the lack of faith of in those in power.

'Responsible journalism' — based on Reynolds ${ }^{24}$ - has been addressed in both Malaysia and Singapore with different outcomes of importance in each legal system. Malaysian courts have accepted the idea of responsible journalism to the extent of critical speech-in principle ${ }^{25}$. Singaporean courts have rejected the rule on all occasions. This rejection of responsible

\footnotetext{
${ }^{20}$ Randhawa et al, (2005) Freedom of Expression and the Media in Malaysia: Part of A Series of Baseline Studies on Seven South East Asian Countries 6.

${ }_{21}^{21}$ Printing Presses and Publications Act 1984 (Act 301).

22 Whiting and Majoribanks, (2013) 'Media Professionals' Perceptions of Defamation and Other Constraints upon News Reporting in Malaysia and Singapore' Democracy, Media and Law in Malaysia and Singapore, 136.

${ }^{23}$ Ibid, 136.

${ }^{24}$ Reynolds $v$ Times Newspapers Ltd [2001] 2.

25 Whiting and Majoribanks, (2013) 'Media Professionals' Perceptions of Defamation and Other Constraints upon News Reporting in Malaysia and Singapore' Democracy, Media and Law in Malaysia and Singapore, 135.
}

Volume 2(S) No. 1 (2015) 
journalism, allowing for appropriate verification, shows that press freedoms do not exist under the legislature or the judiciary in Singapore and are still restrictive in Malaysia ${ }^{26}$.

These restrictions have led to a 'chilling' effect on media, reporting, and journalism in both of the nations, where levels of self-censorship have increased over the last 20 years following exorbitant claims by political and business officials against individual journalists and media outlets. This chilling effect occurs as individuals are deterred from publishing items that they believe could even potentially cause issue for the powerful political parties of the United Malays National Organisation (UMNO) Malaysia and the People's Action Party (PAP) Singapore $^{27}$.

\section{POLITICS OVER MEDIA ORGANISATIONS}

\section{Malaysia and Singapore}

The strength of the PAP in Singapore and the UMNO in Malaysia, along with a concentration of media ownership (aligned with these parties), shows that revenue and business interests fall a close second to the political interests of the affluent politicians in both nations. Although there might be relationships with editors and owners of publishing houses, the political power that the PAP and UMNO have over media organisations damages the credibility of that media by overriding newsworthy items and appropriately balanced coverage ${ }^{28}$. International press is not owned by the politicians; yet, it is closed monitored by the government through the PPPA and the NPPA.

26 Whiting and Majoribanks, (2013) 'Media Professionals' Perceptions of Defamation and Other Constraints upon News Reporting in Malaysia and Singapore' Democracy, Media and Law in Malaysia and Singapore, 135.

27 Thio, (2010) 'Soft Constitutional Law in Non Liberal Asian Constitutional Democracies', 8(4) International Journal of Constitutional Law 766-799.

28 Whiting and Majoribanks, (2013) 'Media Professionals' Perceptions of Defamation and Other Constraints upon News Reporting in Malaysia and Singapore' Democracy, Media and Law in Malaysia and Singapore, 135.

Volume 2(S) No. 1 (2015) 
The alignment of the judiciary, executive, and legislature through the strict controls over publication and access to media has led to a lack of ability for economic prosperity for those companies that do not align themselves with either the PAP or the UMNO. This was apparent when the UMNO aligned The New Straits Times supported the government's prosecution of former Deputy Prime Minister (Ibrahim) on sodomy and corruption charges. The Reformasi rejected this and subsequently had a massive fall in circulation ${ }^{29}$.The courts in both Singapore and Malaysia are concerned with the protection of the reputation of government figure, regardless of the effect on news reporting and commentary ${ }^{30}$.

Media practitioners in Singapore are aware of the threat of defamation cases and aware of what issues constitute sensitive topics and should be avoided-ASEAN, China, race, religion, PAP internal politics, PAP personalities, corruption, and government linked companies ${ }^{31}$. Media practitioners in both Malaysia and Singapore were aware of defamation law. However, most Singaporeans were not fully aware of their legal rights, nor did they have the resources available to them to successfully defend themselves against powerful political players ${ }^{32}$.

Malaysians and Singaporeans considered media and publishing as part of a whole institutional context; where freedom of the press is not a right but that publishing falls within a legislation and regulation, and managing these was simply part of the world of reporting and journalism $^{33}$. The media organisations are aware that there are many restrictions. Thus, draft articles and stories that do not breach these restrictions, the deterrent nature of the legislation, and regulation imposed by Strong hold States being effective in quashing individualism or

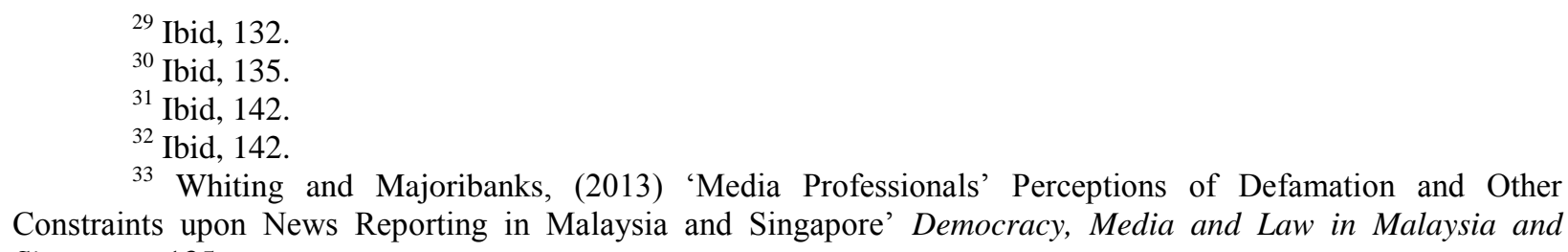


disagreement. Consequently, companies align themselves with the political parties to ensure that they are successful and remain in circulation.

\section{MEDIA ORGANISATIONS OVER POLITICS}

\section{The United Kingdom (UK) and The United States of America (USA)}

In evaluating media organisation control in both of the UK and the USA, a focal corporation in place of a Strong hold State should be assessed. NewsCorp (owned by Rupert Murdoch) allows for an effective assessment of the role that media organisations (conglomerates) negotiate political powers and what media is released to the public to benefit their economic goals ${ }^{34}$. NewsCorp media reaches approximately $75 \%$ of the world's population over five continents with around \$28 billion in annual revenue.

Their power over press freedoms and access to the media makes them may have no competitor. In 2003, the 175 NewsCorp controlled newspapers supported Murdoch's personal stand for the invasion to Iraq; which was also supported by the Georg W Bush and Tony Blair (USA and UK leaders at the time) $^{35}$. Murdoch has used the NewsCorp publications to back those political policies that support the NewsCorp group. The power of NewsCorp and the financial dealings of the company mean that regulators are sometimes hesitant to enforce laws for fear of ramifications by NewsCorp publications ${ }^{36}$.

The power of NewsCorp throughout the UK, the USA, and Australia has led to a large interference with politics and election cycles. This political leverage leads to the presentation of regulatory favours for NewsCorp entities and subsidiaries assisting with the growth of NewsCorp entities leading to more regulatory freedoms which increase the company and

\footnotetext{
${ }^{34}$ Arsenault and Castells, (2008) 'Switching Power: Rupert Murdoch and the Global Business of Media Politics: A Sociological Analysis, 23(488), International Sociology, 489.

35 Ibid, 493.

${ }^{36}$ Arsenault and Castells, (2008) 'Switching Power: Rupert Murdoch and the Global Business of Media Politics: A Sociological Analysis, 23(488), International Sociology, 496.
}

Volume 2(S) No. 1 (2015) 
escalate its political influence ${ }^{37}$. The political alliances made by NewsCorp are fickle. It reflects the business and economic interests of NewsCorp rather than any deep seeded political affiliation; contradictory to the political power and business affiliation in both Singapore and Malaysia $^{38}$

NewsCorp has historically provided direct financial contributions to politicians and political parties (US\$ 4.7 million between 1998 and 2007) ${ }^{39}$. The media regulatory review generally coincides with the contributions from NewsCorp. As in 2006, NewsCorp provided $10 \%$ of campaign contributions to Senator Ted Stevens, during which period Stevens was sponsoring a telecommunications bill that assisted with the NewsCorp business objectives. Similarly, HarperCollins, a NewsCorp owned company has provided book deals to politicians who then supported media regulatory changes ${ }^{40}$.

NewsCorp has also been credited with shifting the outcome of the 1997 British Election of Tony Blair as prime minister-New Labour, when NewsCorp was historically Conservative and in support of Margaret Thatcher. Shortly before the election, all NewsCorp print media outlets endorsed Tony Blair for the Prime Minister role; which he subsequently won. New Labour has a favourable position on media regulation in contrast with the more accountable stance of the Conservative party at the time ${ }^{41}$. Increased revenue and market share have led to NewsCorp being able to gain regulatory favours from politicians via financial contributions to their campaigns ${ }^{42}$. This increases the power had by media organisations (conglomerates) over politics, whilst still controlling access to media and press freedoms.

\footnotetext{
${ }^{37}$ Ibid, 497.

${ }^{38}$ Ibid, 497

${ }^{39}$ Ibid, 497.

${ }^{40}$ Ibid, 499.

${ }^{41}$ Arsenault and Castells, (2008) 'Switching Power: Rupert Murdoch and the Global Business of Media Politics: A Sociological Analysis, 23(488) International Sociology, 500.

42 Ibid, 507.
} 


\section{CONCLUSION}

\section{Press Freedoms}

By analysing the presentation of legislation and political power in Malaysia and Singapore contrasted with economic powers in the UK and the USA; it is clear to see that regardless of who hold the power political parties or media organisation there appears to be an intrinsic link between the two. This power and influence has led to restrictions being placed on what journalists and reporters publish and what is accessible by the masses.

\section{Defamation Legislation}

Defamation legislation creates chilling effect in Malaysia and Singapore which means that the level of litigation is no longer high as journalists are self-censoring to minimise their risk of personally being taken to court. It is important to note that although defamation legislation is not as restrictive; however, in the UK and the USA it does exist. Wider understanding between general population, report of individual legal rights, and more accessible independent judiciaries allow for the appropriate application of defamation legislation taking into consideration notions of responsible journalism.

It is fair to say that those restrictions and regulations present in Malaysia and Singapore as strong hold states are less plaintiff friendly and more intensive. Nevertheless, it is clear that with the removal of this global media companies and their influences on political parties and policy, it regulates and restricts what is published in the media for access by the public. 


\section{REFERENCES}

Journals:

Arsenault and Castells, (2008) 'Switching Power: Rupert Murdoch and the Global Business of Media Politics: A Sociological Analysis’ International Sociology.

Article 19 and Suaram, (2005) Freedom of Expression and the Media in Malaysia.

Randhawa et al, (2005) Freedom of Expression and the Media in Malaysia: Part of A Series of Baseline Studies on Seven South East Asian Countries.

Thio, (2010) 'Soft Constitutional Law in Nonliberal Asian Constitutional Democracies' 8(4) International Journal of Constitutional Law.

Whiting and Majoribanks, (2013) 'Media Professionals' Perceptions of Defamation and Other Constraints upon News Reporting in Malaysia and Singapore' Democracy, Media and Law in Malaysia and Singapore

Laws:

Constitution of Malaysia 1957 art X.

Defamation Act 1957 (Malaysia)

Defamation Act 1985 (Singapore)

Defamation Act 2013 (UK)

Newspaper and Printing Presses Act (rev, 2002 edition) (Singapore)

Printing Presses and Publications Act 1984 (Malaysia)

United States Constitution amend I.

\section{Cases:}

Reynolds v Times Newspapers, Ltd. [2001] 2. 